\title{
Аналіз впливу психосоціальних факторів на результат фізіотерапевтичного втручання при болю в нижній частині спини
}

\author{
УДК 611.959:615.825:616-071
}

\section{А. Згурський, Я. Закаблуцький, С. Федоренко}

\author{
Національний університет фізичного виховання і спорту України, Київ, Україна
}

\begin{abstract}
Резюме. Мета. На основі аналізу сучасних наукових та клінічних досліджень проаналізувати вплив психосоціальних факторів на результати фізіотерапевтичного втручання при болю в нижній частині спини. Методи. Аналіз та узагальнення зарубіжних даних спеціальної науковометодичної літератури, що стосуються основних підходів до процесу фізичної терапії болю в нижній частині спини; синтез та узагальнення. Результати. Проведений аналіз останніх наукових робіт показав, що існує багато досліджень, які описують вплив психосоціальних факторів на відновлення пацієнтів з неспецифічним болем у попереку. Кінезіофобія, катастрофізація уникнення страху мають прогностичні значення в розвитку хронічного болю. Однак існує обмежена кількість робіт стосовно впливу психосоціальних факторів на результат фізичної терапії та відповідність пацієнтів певним методам фізичної терапії. Враховуючи значний вплив на стан пацієнтів таких психосоціальних факторів, як кінезіофобія, катастрофізація, уникнення страху, необхідно володіти достатніми навиками, щоб вміти виявляти їх. Це дозволить на ранніх етапах виявляти пацієнтів з підвищеним ризиком розвитку хронічного болю і застосовувати відповідні багатокомплексні методи терапевтичного втручання з можливим залученням інших спеціалістів. Оскільки основними тригерами болю у таких пацієнтів можуть бути саме психосоціальні фактори, це може суттєво впливати на результат фізіотерапевтичного втручання. У літературі можна знайти достатньо рекомендацій до застосування скринінгових інструментів психосоціальних факторів для визначення прогностичних факторів ризику болю в нижній частині спини. Однак подібні інструменти дозволяють лише класифікувати пацієнтів на підгрупи за факторами ризику і не допомагають у визначенні та застосуванні певних методів фізичної терапії, враховуючи важкість стану пацієнта. Зважаючи на ці факти, виникає необхідність сконцентруватися на дослідженнях, які будуть спрямовані на вивчення застосування можливих методів та підходів фізичної терапії відповідно до визначених прогностичних факторів ризику болю в нижній частині спини.
\end{abstract}

Ключові слова: фізична терапія, реабілітація, неспецифічний біль у попереку, хронічний біль у попереку, психосоціальні фактори.

Analysis of the influence of psychosocial factors on the outcome of physical therapy intervention for lower back pain

\section{A. Zgurskyi, Ya. Zakablutskyi, S. Fedorenko}

National University of Physical Education and Sport of Ukraine, Kyiv, Ukraine

Abstract. Objective. Based on the analysis of modern scientific and clinical studies to analyze the influence of psychosocial factors on the outcome of physiotherapy intervention for lower back pain. Methods. Analysis and generalization of foreign data of special scientific and methodical literature concerning the main approaches to the process of physical therapy of pain in the lower back; synthesis and generalization. Results. An analysis of recent research has shown that there are many studies that describe the impact of psychosocial factors on the recovery of patients with nonspecific low back pain. Kinesiophobia, catastrophic fear avoidance have prognostic significance in the development of chronic pain. However, there is a limited amount of work on the impact of 
psychosocial factors on the outcome of physical therapy and the compliance of patients with certain methods of physical therapy. Given the significant impact on the condition of patients of such psychosocial factors as kinesiophobia, catastrophization, avoidance of fear, it is necessary to have sufficient skills to be able to detect them. This will allow in the early stages to identify patients at increased risk of developing chronic pain and apply appropriate multi-complex methods of therapeutic intervention with the possible involvement of other specialists. As the main triggers of pain in such patients may be psychosocial factors and this can significantly affect the outcome of physiotherapy. There are enough recommendations in the literature for the use of psychosocial factors screening tools to determine the prognostic risk factors for lower back pain. However, such tools only allow patients to be classified into subgroups according to risk factors and do not help in the definition and application of certain methods of physical therapy, given the severity of the patient's condition. Given these facts, there is a need to focus on research that will focus on the application of possible methods and approaches to physical therapy in accordance with certain prognostic risk factors for lower back pain.

Keywords: physical therapy, rehabilitation, nonspecific low back pain, chronic low back pain, psychosocial factors.

Постановка проблеми. Біль у попереку $є$ однією з провідних причин порушення діяльності опорно-рухового апарату та найпоширенішою причиною звернення за медичною допомогою у світі. Згідно зі статистичними даними, більше $80 \%$ людей у світі хоч раз у житті зіштовхуються з болем у попереку [1]. Хоча більшість 3 пацієнтів і одужують протягом чотирьох тижнів, але у $23 \%$ випадків продовжують розвиватися хронічні симптоми, а 11-12 \% хворих вважаються непрацездатними 3 приводу хронічного болю [1].

При терапії хронічного болю в попереку використовують різні підходи, в першу чергу рекомендується консервативне лікування [2]. В більшості випадків консервативне лікування складається 3 фрізичної терапії та освіти пацієнтів [2].

Фізіотерапевтичне втручання планується на основі клінічного огляду фрізичного терапевта. В більшості випадків огляд фрізичного терапевта фокусується на фрізикальному огляді і має на меті оцінити можливі порушення постави, обмеження амплітуди руху, сили м'язів і т.п. [3]. Останнім часом багато уваги було звернуто до оцінки психосоціальних фракторів як можливих причин та фракторів ризику виникнення хронічного болю в попереку. Виявлення та вивчення психосоціальних факторів дозволяє спрогнозувати прогресування від первинного епізоду гострого болю в попереку до хронічного [4].

Застосування методів фізикального огляду в поєднанні зі скринінгом психосоціальних факторів дозволить диференціювати пацієнтів за ступенем ризику виникнення хронічного болю в попереку.

Краще розуміння взаємозв'язку між психосоціальними фракторами та методами фрізичної терапії дозволить розробити відповідні алгоритми терапевтичного втручання для кожної категорії.
У літературі можна зустріти багато досліджень, які вивчають прогностичні фактори, що впливають на клінічний результат $[5,6]$. До прогностичних психосоціальних фракторів належать характеристики, які допомагають оцінити ймовірний результат пацієнта незалежно від обраного лікування. Епідеміологічна література стосовно болю в нижній частині спини свідчить, що сильним прогностичним факторомдлястійкихсимптомівєдепресія [15].

J. A. Hayden et al. [5] провели поглиблений систематичний огляд оцінки потенційно релевантних, прогностичних фракторів. До фрізичних факторів автори віднесли вік, стать, інтенсивність болю, індекс маси тіла та неврологічні симптоми. Психосоціальні фактори включали важкість функціональних порушень, попередній досвід лікування, депресію, соматизацію, переконання щодо уникнення страху, самоефективність, стратегії подолання, попередню історію хвороби, попередній досвід болю, задоволеність роботою.

Результати фрізіотерапевтичного втручання різняться і вимірюються за допомогою оцінювання інтенсивності болю та порушення життєдіяльності. Кілька фракторів потенційно можуть вплинути на ці результати. У вторинному аналізі даних проспективної когорти змішаної групи пацієнтів з хронічним та гострим болем у попереку $(n=111)$, які отримували амбулаторну фрізичну терапію, оцінювали результати через шість місяців. Між пацієнтами, які одужали $(12,6 \%)$ та не одужали, порівнювали ряд показників, серед яких були психологічні, больові та показники порушення життєдіяльності. Через шість місяців у пацієнтів, які не одужали, було більше ознак поведінки уникнення страху, кінезіофробії і депресивних симптомів ( $<0,001)$ порівняно з тими, які одужали. На основі аналізу дискримінантної фрункції було виявлено, що уникнення страху, кі- 
незіофобія і симптоми депресії вносять значний вклад у прогнозування відновлення після фрізичної терапії [13].

Метою систематичного огляду A. Alhowimel et al. [14] було виявлення психологічних фракторів, пов'язаних зі змінами показників болю або інвалідності у пацієнтів з хронічним болем у попереку після фрізичної терапії. Хоча цей огляд доволі широкий, але все ж таки простежується зв'язок між психологічними фракторами, включаючи кінезіофоббію, катастрофрізацію та самоефективність, і показниками болю та інвалідності при терапії пацієнтів з хронічним болем у нижній частині спини. Це свідчить про те, що ці фрактори потребують додаткової оцінки для подальшого планування терапевтичного втручання. В майбутніх роботах слід дослідити ефективність фрізіотерапевтичних втручань з урахуванням психосоціальних фракторів.

Мета дослідження - на основі аналізу сучасних наукових та клінічних досліджень проаналізувати вплив психосоціальних фракторів на результати фрізіотерапевтичного втручання при болю в нижній частині спини.

Методи дослідження: аналіз та узагальнення зарубіжних даних спеціальної науковометодичної літератури, що стосується основних підходів до процесу фізичної терапії пацієнтів 3 неспецифічним болем у спині.

Результати дослідження та їх обговорення. Рекомендації до консервативного лікування неспецифічного болю в попереку включають фізичну терапію в першій лінії терапевтичного втручання. Терапевтичні вправи є основним методом фрізичної терапії, які можна доповнювати пасивними методами, такими як мануальна терапія та освіта пацієнтів [2].

Smeets et al. [16] підкреслюють, що фрізичні вправи спрямовані на розвиток аеробних можливостей, збільшення сили та витривалості м'язів спини, можуть зменшити біль, який пов'язаний з катастрофрізацією. Слід зазначити, що в цьому дослідженні терапевтичне втручання не було свідомо спрямоване на когнітивні фрактори. Це свідчить про те, що терапія зосереджена на зменшенні катастрофрізації болю і може успішно застосовуватися фрізичним терапевтом з використанням фрізичних вправ.

Визначення алгоритму терапевтичного втручання залежить від стану пацієнта та його індивідуальних особливостей. Існує багато індивідуальних характеристик, що можуть впливати на прогноз і план відновлення пацієнтів з болем у нижній частині спини. До психологічних характеристик належать депресія, тривога, посттрав- матичний стресовий розлад, уникнення страху, катастроорізація, кінезіофобія, погані стратегії подолання, погана самоефективність та вже існуюча соматизація [7-9]. До соціальних характеристик належать відсутність на роботі, ізоляція, законодавство, системи компенсації та соціально-економічна інфрраструктура [7, 10, 11].

У великому обсерваційному дослідженні пацієнтів з болем у нижній частині спини було розглянуто 20 потенційних психологічних прогностичних фракторів. I хоча всі 20 фракторів були суттєво прогнозованими, спостерігався високий ступінь перекриття серед змінних. Лише кілька змінних, включаючи самоефективність, сприйняття особистого контролю, катастрофрізацію або очікування результату, ідентичність захворювання, були незалежними прогностичними факторами. Це дослідження підкреслило, як багато психосоціальних фракторів взаємопов'язані, а отже, $\epsilon$ необхідність виявлення потенційних фракторів для досягнення найбільш ефективної прогностичної оцінки [17].

Оскільки існують численні психосоціальні змінні, які мають певне прогностичне значення, пропонується розробити розширені стратегії терапії, які допоможуть фрізичним терапевтам завадити розвитку стійких клінічних симптомів. Це вимагатиме більш вузького зосередження на кількох психологічних фракторах [17]. Саме тому багато уваги було приділено оцінюванню та вивченню впливу на одужання пацієнтів з хронічним болем у попереку таких психологічних фракторів, як кінезіофобія і катастрофрізація. В огляді 25 перспективних когортних досліджень T. Pincus et al. [4] повідомили, що уникнення страху, депресія та катастрофрізація $€$ предикторами прогресування від гострого епізодичного до хронічного болю в попереку.

Подібним чином у систематичному огляді M. M. Wertli et al. [12] припустили, що наявність поведінки уникнення страху пов'язана з поганим одужанням.

Існує кілька прикладів інструментів скринінгу болю в нижній частині спини, які беруть до уваги наявність психосоціальних фракторів. Одним 3 інструментів оцінювання на етапі первинної медико-санітарної допомоги $€$ «Keele STarT Back Screening Tool», який дозволяє розділити пацієнтів на підгрупи. Такий підхід допомагає обрати методи терапії відповідно до стану пацієнта з урахуванням психосоціального впливу на процес відновлення [18]. Іншою формою скринінгу $\epsilon$ опитувальник м'язово-скелетного болю Örebro (ÖMPSQ).

Вищевказані скринінгові інструменти допомагають виявити прогностичні фрактори ризику для 
класифікації пацієнтів за групами для розроблення багатокомпонентних методів терапії. Але необхідно розуміти, що це корисно лише для виявлення статусу ризику пацієнта, а не для встановлення відповідності пацієнтів певним методам фрізичної терапії. На сьогодні існує лише один систематичний огляд, який дозволяє оцінити вплив кінезіофоббії, катастрофрізації та самоефективності на результат фрізичної терапії пацієнтів 3 хронічним болем у попереку [14]. Не зрозуміло, яким чином прогностичні фрактори можуть допомогти клініцистам передбачити відповідь на методи фрізичної терапії (мануальна терапія, фрізичні вправи або і те, й інше), оскільки такі фрактори були пов'язані з результатом незалежно від лікування і не були визначені як модератори конкретних ефректів терапії [19]. Це питання залишається відкритим і потребує подальшого вивчення.

Висновки. Враховуючи значний вплив на стан пацієнтів таких психосоціальних факторів, як кінезіофобія, катастрофрізація, уникнення страху, необхідно володіти достатніми навиками, щоб вміти їх помічати. Це дозволить на ранніх

\section{Література}

1. Balagué $F 1$, Mannion AF, Pellisé F, Cedraschi C. Non-specific low back pain. Lancet. 2012 Feb 4;379(9814):482-91.

2. Low back pain and sciatica in over $16 \mathrm{~s}$ : assessment and management. NICE guideline [NG59] Published: 30 November 2016 Last updated: 11 December 2020.

3. Clinical Practice Guidelines Linked to the International Classification of Functioning, Disability, and Health from the Orthopaedic Section of the American Physical Therapy Association. Journal of Orthopaedic \& Sports Physical Therapy Published Online: 2012 April 1; 42(4):A1-A57.

4. Pincus T, Burton AK, Vogel S. A systematic review of psychological factors as predictors of chronicity/disability in prospective cohorts of low back pain. Spine 2002;27:E109-E120.

5. Hayden JA, Dunn KM, van der Windt DA et al. What is the prognosis of back pain? Best Pract Res Clin Rheumatol. 2010;24:167-79.

6 . Chou R, Shekelle P. Will this patient develop persistent disabling low back pain? JAMA. 2010;303:1295-1302.

7. Pincus T, Kent P, Bronfort G, Loisel P, Pransky G, Hartvigsen J. Twenty-five years with the biopsychosocial model of low back pain-is it time to celebrate? A report from the twelfth international forum for primary care research on low back pain. Spine. 2013;38(24):2118-23.

8. Generaal E, Vogelzangs N, Penninx BW, Dekker J. Insomnia, sleep duration, depressive symptoms, and the onset of chronic multisite musculoskeletal pain. Sleep 2017 1;40(1). PubMed PMID: 28364456.

9. Leung L. Pain catastrophizing: an updated review. Indian J Psychol Med 2012;34(3):204-17. PubMed PMID: 23441031. Pubmed Central PMCID: 3573569 .

10. Eisenberger NI. The pain of social disconnection: examining the shared neural underpinnings of physical and social pain. Nat Rev Neurosci. 2012;13(6):421-34.

physiorehabkyiv@gmail.com етапах виявляти пацієнтів з підвищеним ризиком розвитку хронічного болю і застосовувати відповідні багатокомплексні методи терапевтичного втручання з можливим залученням інших спеціалістів. Оскільки основними тригерами болю у таких пацієнтів можуть бути саме психосоціальні фактори, це може суттєво впливати на результат фрізіотерапевтичного втручання.

У літературі можна знайти достатньо рекомендацій до застосування скринінгових інструментів психосоціальних фракторів для визначення прогностичних фракторів ризику болю в нижній частині спини. Однак подібні інструменти дозволяють лише класифрікувати пацієнтів на підгрупи за фракторами ризику і не допомагають у визначенні та застосуванні певних методів фрізичної терапії, враховуючи важкість стану пацієнта. Зважаючи на ці фракти, виникає необхідність сконцентруватися на дослідженнях, які будуть спрямовані на вивчення застосування можливих методів та підходів фрізичної терапії відповідно до визначених прогностичних фракторів ризику болю в нижній частині спини.

11. Sturgeon JA, Dixon EA, Darnall BD, Mackey SC. Contributions of physical function and satisfaction with social roles to emotional distress in chronic pain: a collaborative health outcomes information registry (CHOIR) study. Pain. 2015;156(12):2627-33.

12. Wertli MM, Rasmussen-Barr E, Held U. Fear-avoidance beliefs - a moderator of treatment efficacy in patients with low back pain: a systematic review. Spine J 2014;14(11):2658-78.

13. George SZ, Beneciuk JM. Psychological predictors of recovery from low back pain: a prospective study. BMC Musculoskelet Disord 2015;16:49.

14. Ahmed Alhowimel, Mazyad AlOtaibi, Kathryn Radford, Neil Coulson. Psychosocial factors associated with change in pain and disability outcomes in chronic low back pain patients treated by physiotherapist: A systematic review. SAGE Open Med. 2018 Feb 6;6:2050312118757387.

15. Croft PR, Dunn KM, Raspe H. Course and prognosis of back pain in primary care: the epidemiological perspective. Pain. 2006;122:1-3

16. Smeets RJ, Vlaeyen JW, Kester $A D$ et al. Reduction of pain catastrophizing mediates the outcome of both physical and cognitive-behavioral treatment in chronic low back pain. J Pain. 2006;7:261-71.

17. Foster NE, Thomas $E$, Bishop $A$, et al. Distinctiveness of psychosocial obstacles to recovery in low back pain patients in primary care. Pain. 2010;148:398-406.

18. Beneciuk JM, Bishop MD, Fritz JM, Robinson ME, Asal NR, Nisenzon AN et al. The STarT Back Screning Tool and individual psychological measures: evaluation of prognostic capabilities for low back pain clinical outcomes in outpatient physical therapy settings' Physical Therapy, 2012.

19. Underwood MR, Morton V, Farrin A. Do baseline characteristics predict response to treatment for low back pain? Secondary analysis of the UK BEAM dataset [ISRCTN32683578]. Rheumatology. 2007;46:1297-1302. 